\title{
Born Globals: Investigating The Influence Of Their Business Models On Rapid Internationalization
}

Ricarda B. Bouncken, University of Bayreuth, Germany

Miriam Muench, University of Liechtenstein, Liechtenstein

Sascha Kraus, University of Liechtenstein, Liechtenstein

\begin{abstract}
The distinguishing characteristic of a business model is the way in which the type of product or service is linked to a particular group of customers using a specific communication and delivery method. The authors argue that the distinctive characteristic of BGs of foreign sales from the outset, or very quickly afterward, may be due to differences in their business models and their ability to adapt them to foreign markets. In contrast to other internationalization theories, the business model approach focuses on the holistic view of the firm's core activities in which business model innovation plays a pivotal role to gain competitive advantages. Thus, a business model is a strategic and dynamic value-creation process that is adapted to foreign markets - a main accelerator of the rapid internationalization of BGs.
\end{abstract}

Keywords: Born Global; International New Venture; Business Model; Internationalization

\section{INTRODUCTION}

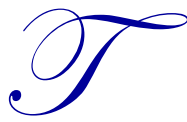

he volume of global business has increased dramatically during the past decades and has forced more and more small companies to start their international activities right after their inception (Knight \& Cavusgil, 2004; Oviatt \& McDougall, 1994; Rennie, 1993; Welch \& Luostarinen, 1988). The trend has been hastened by the rapid development of advanced communication technology, which accelerates the transfer of information around the globe and facilitates the expansion of global networks and alliances (Knight \& Cavusgil, 2004; Moen, 2002). Besides the ability to conduct global business much more efficiently, the increasing importance of niche markets plays a further important role because it forces small firms into small niches in several countries in order to be competitive (Almor, 2013; Moen, 2002).

Given the increasing number of firms that can be classified as born global (BG) and their potential to become a leading species in the ecosystem of international trade, the phenomenon BG has become an important driver of international entrepreneurship research in the past decade (Andersson, 2011; Knight \& Cavusgil, 2004; Kraus, 2011; Moen, 2002; Moen et al., 2008). The distinguishing characteristic of BGs is that they start internationalizing rapidly, right after their foundation or soon afterward (Chetty \& Campbell-Hunt, 2004; Moen \& Servais, 2002; Phillips McDougall et al., 1994) and "sell a high share of their output abroad" (Hennart, 2014, p. 117). Furthermore, Fan and Phan (2007) argue that the uniqueness of BGs is related to their business models. Onetti et al. (2012) argue that the survival and success of a BG depends on effective business model design, where decisions about core activities and where to focus investments are interconnected to decisions about location of activities, and about inward and outward relationships with other players. 


\section{RESEARCH REVIEW}

\section{Internationalization Theory}

Theoretical explanations about why and how BGs seek to internationalize are still incomplete, especially with respect to accelerated internationalization (Bouncken et al., 2015; Knight \& Cavusgil, 1996, 2004; Oviatt \& McDougall, 2005). Hennart (2014) describes BGs even as accidental internationalists because in "acquiring foreign customers is [...] no different than acquiring domestic ones" (p. 118). So far, empirical definitions for BGs vary significantly. While Evers (2010) suggests $25 \%$ of total sales in foreign countries in the first year of trading, Chetty and Campbell-Hunt (2004) set a benchmark of 75\% export intensity within two years of inception. In general, recent research agrees that BGs start international activities early after inception and have a high speed, degree and scope of internationalization as core characteristics (Cesinger et al., 2012; Freeman \& Cavusgil, 2007).

\section{Two Views Of Internationalization}

The Uppsala internationalization model, also called incremental stages theory, based on learning theory, describes internationalization as a dynamic and evolutionary process in which the company enhances its international activities gradually in single phases (Johanson \& Vahlne, 1977, 1990). The the status quo alternates cyclically with a state of change. Before a change is initiated, first market commitment and market knowledge must be generated in a company and, based on the gained experience, new decisions in terms of the internationalization can be made (Forsgren, 2002; Steen \& Liesch, 2007).

Whereas traditional firms focus on the domestic market for many years and gradually internationalize their operations by building up experience and commitment step by step, BGs have a global view of their markets from the beginning and jump straight from the domestic to the global phase, a phenomenon also known as leapfrogging, and psychic distance plays only a minor role in the internationalization process (Bell et al., 2003; Fink et al., 2008; Gabrielsson et al., 2012; Knight \& Cavusgil, 2004).

\section{Individual-Level Variables}

The traditional internationalization model no longer seems sufficient to explain the phenomenon of BGs because they are particularly defined by differing from the traditional approach and not following a regular path of internationalization. Hence, conceptual explanations of accelerated internationalization by BGs divided in three dimensions of the research area will be illustrated. Regarding the first dimension, the level of the individual, the manager or the entrepreneur acting with an international orientation from the outset seems to be the key element for rapid internationalization of BGs by combining both the international business experience and the international network of individuals and firms (Andersson, 2011; Freeman \& Cavusgil, 2007; Knight \& Cavusgil, 2004; Park \& Rhee, 2012). According to the knowledge-based view which puts the individual in the center of the learning process, managers in BG firms have developed specific learning strategies that help them to acquire new knowledge very fast (Bingham \& Davis, 2012; Grant, 1996).

\section{Firm-Level Variables}

The resource-based view (RBV) has emerged as one of the dominant frameworks in research on BG internationalization and is based on the theory that BGs possess unique firm-specific resources that allow them to compete in international markets (Autio, 2005; Jones et al., 2011; Knight \& Cavusgil, 2004). Recent literature has defined them as technological, organizational, relational and human resources (Barney, 1991; Rialp et al., 2005). In this context dynamic capabilities play a leading role because they describe the ability of the organization to integrate external knowledge (Eisenhardt \& Martin, 2000; Jantunen et al., 2008; Teece, 2007). In a nutshell, several authors have shown in their studies the link between unique resources of a company and the scope and progress of internationalization (Dhanaraj \& Beamish, 2003; Westhead et al., 2001).

A further dominant approach is the network perspective, which includes not only internal development of a firm's knowledge and resources but also the market and the relationship of the firm to that market (Freeman \& 
Cavusgil, 2007). Because of their liability of smallness, BGs are limited by the resources available and have developed strategies to overcome these limitations by using networks and alliances, thus to accelerate their entrance to foreign markets by using non-equity modes of entry (Acedo \& Jones, 2007; Autio, 2005; Freeman et al., 2006; Hennart, 2014; Moen, 2002; Oviatt \& McDougall, 1994). Several researchers stress the importance of network relationships as a moderating influence on speed of internationalization (Madsen \& Servais, 1997; Oviatt \& McDougall, 2005).

\section{National-Level Variables}

While the emergence of BGs is reported with increasing frequency all over the world, they seem to emerge frequently in small countries with advanced economies in which also reductions in communication and transportation costs have played an important role (Almor, 2013; Fan \& Phan, 2007; Gabrielsson \& Manek Kirpalani, 2004; Knight \& Cavusgil, 1996; Madsen \& Servais, 1997; Oviatt \& McDougall, 1994; Schuessler et al., 2014). Hence, the research dimension of the national level constitutes that "the smaller a firm's home country [...] the more likely it will be [a BG]" (Hennart, 2014, p. 127).

To sum up, accelerated internationalization is divided into three research areas that try to explain the emergence of BGs, but they are not entirely satisfactory. Furthermore, the born-global model holds that firm strategy plays a central role in rapid internationalization, but it is still undetermined which particular features of the business model, a reflection of the realized strategy, contribute to their performance in international markets (CasadesusMasanell \& Ricart, 2010; Chetty \& Campbell-Hunt, 2004; Jantunen et al., 2008).

\section{Business Model}

Internationalization leads to globalized competition, not only in the value proposition of offerings in a domestic context but also in the global sourcing and allocation of resources and activities. Thus, "when a firm decides to internationalize its activities, its focus is on business-model innovation" (Rask, 2014, p. 147).

\section{Developing The Term 'Business Model'}

The authors' review of the literature reveals that the term did not see widespread use for decades and very few authors focus on internationalization, but it quickly gained prominence among both business scholars and practitioners with the emergence of internet companies and the development of information and communication technologies (DaSilva \& Trkman, 2013; Gray \& Farminer, 2014; Onetti et al., 2012; Osterwalder \& Pigneur, 2005).

According to Teece (2010), business models describe "the design or architecture of the value creation, delivery, and capture mechanisms" that a venture employs, and the essence is in "defining the manner by which the enterprise delivers value to customers, entices customers to pay for value, and converts those payments to profit" (p. 172). However, a more dynamic view of the term is given by Zott and Amit (2013) who suggest that a business model describes the system of interdependent activities that are performed by the firm and by its partners and the mechanisms that link these activities to each other. Thus, a business model can be viewed as a template that depicts the way a firm conducts its business, how it delivers value to stakeholders, and how it links factor and product markets.

Despite the growing importance of the business model concept, there is an ambiguity of definitions because these are fairly heterogeneous and none appears to be generally accepted. Therefore, as a step towards a common definition, the authors compared previous definitions and synthesized the characteristics of the term. Many scholars acknowledge the centrality in business models of the creation, capture and delivery of value to an organization's customers (Chesbrough, 2010; Teece, 2010). Furthermore, according to Onetti et al. (2012) the most cited business model components are: "Process/Activities/Value Chain", "Customer (Relationship/Interface)" and "Value Network (Partners/Actors/Suppliers/Alliances)" (p. 357). Moreover, the authors found hints concerning the nature of business models as adapted to foreign markets which need to be considered as a growth component when defining the scope of business model and they have implemented this view. Being the first to incorporate all these characteristics of the business model in one definition, the authors propose that: 
A business model is a strategic and dynamic value-creation process among a value network that is characterized by the way the type of product or service is linked to a particular group of customers using a specific communication and delivery method and accelerates, by adaptation, the early internationalization process.

\section{Business Models And Gaining Sustainable Competitive Advantage}

Richardson (2008) and Osterwalder and Pigneur (2005) propose a consolidated view of the three main elements of a business model (Figure 1): the value proposition, including the product/service offering and the target customer segments and relationships; the value creation and delivery system as the heart of the business model containing the key activities, resources, channels, partners and technology; and the value capture that is conducted by seizing new business opportunities, new markets and new revenue streams.

\section{Value Proposition $\quad$ Value Creation \& Delivery $\quad$ Value Capture}

Source: Own figure based on Richardson (2008) and Osterwalder and Pigneur (2005)

Figure 1: A Conceptual Business Model Framework

However, a framework for the business model that centers on company activities is proposed by Onetti et al. (2012) and uses "focus", "modus" and "locus" as analytical building blocks of the business model concept (Figure 2), whereby:

1. Focus decisions concern the allocation of company resources to different activities and provide the basis of the firm's value proposition. The business model defines the relevance of the different activities and determines the span of the value chain by identifying what activities the company is focused on.

2. Locus decisions refer to where the different activities of the company take place and it has to be decided in which geographical areas or industrial clusters several activities are carried out. Thus, the business model determines the geographical configuration of the value chain.

3. Modus decisions design the way a company operates in selecting the management method for each activity by defining which activities to manage in-house and which ones to outsource. Therefore, the level of company integration (make or buy), its internal production structure (labor, capital or technology based), and its external network architecture (its network approach) shall be determined as a result of the business model's decisions.

Hence, the business model spans the boundaries of the company and structures its value network which includes customers, suppliers, partners and distribution channels that extend the company's own resources (Onetti et al., 2012; Zott \& Amit, 2008).

\begin{tabular}{|c|c|c|l|}
\hline & Focus & Locus & \multicolumn{1}{c|}{ Modus } \\
\hline Activity A & How much to allocate? & Where? & $\begin{array}{l}\text { Who? In-house or third parties? } \\
\text { How capital- or labor-intensive? } \\
\text { How much tech-intensive? }\end{array}$ \\
\hline Activity B & & & \\
\hline
\end{tabular}

Source: Onetti et al. (2012, p. 360)

Figure 2: An Activity-Driven Business Model Framework

Having a differentiated and difficult-to-imitate architecture for an enterprise's business model is important to establish competitive advantages and can be achieved through various elements that work well together as a system and are co-specialized to each other (McGrath, 2010; Teece, 2010). In this context, business-model innovation plays an important role that involves the creation, or reinvention, of the business itself. Internal factors, such as a strong intellectual property protection or complicated process steps, as well as external factors concerned with customers, suppliers and the broader environment, need to be assessed for a good business-model design and implementation to achieve competitive advantages (Teece, 2010). Moreover, in a large sample and cross-sectional empirical analysis of young firms, Zott and Amit (2013) found that introducing novel business models positively influences performance and so facilitates early and rapid internationalization through competitive advantage. 


\section{Impact On Accelerated Internationalization}

Many BGs are found to be involved in advanced niche technologies or knowledge-intensive industries, which implies that dispersed specialized suppliers and customers in different countries can understand and trade with each other more easily than their counterparts in non-specialized mass markets, because the cultural distance that impedes the conduct of business is overcome by the 'domain-specific familiarity' among specialists (Autio et al., 2000; Bell, 1995; Fan \& Phan, 2007; Young, 1987). Hence, the shared knowledge between buyers and sellers of niche products trumps the psychic distance and potential markets may be reached simultaneously.

Rask (2014) offers a fruitful conceptual study by outlining four types of business models, highlighting their international dimensions and illustrating possible paths in the process of internationalization through business-model innovation, as shown in Figure 3. Thereby, one path from domestic to export-based business models is followed by one from export to semi-global business models. The other path goes from domestic through import-based business models to also end in semi-global business models.

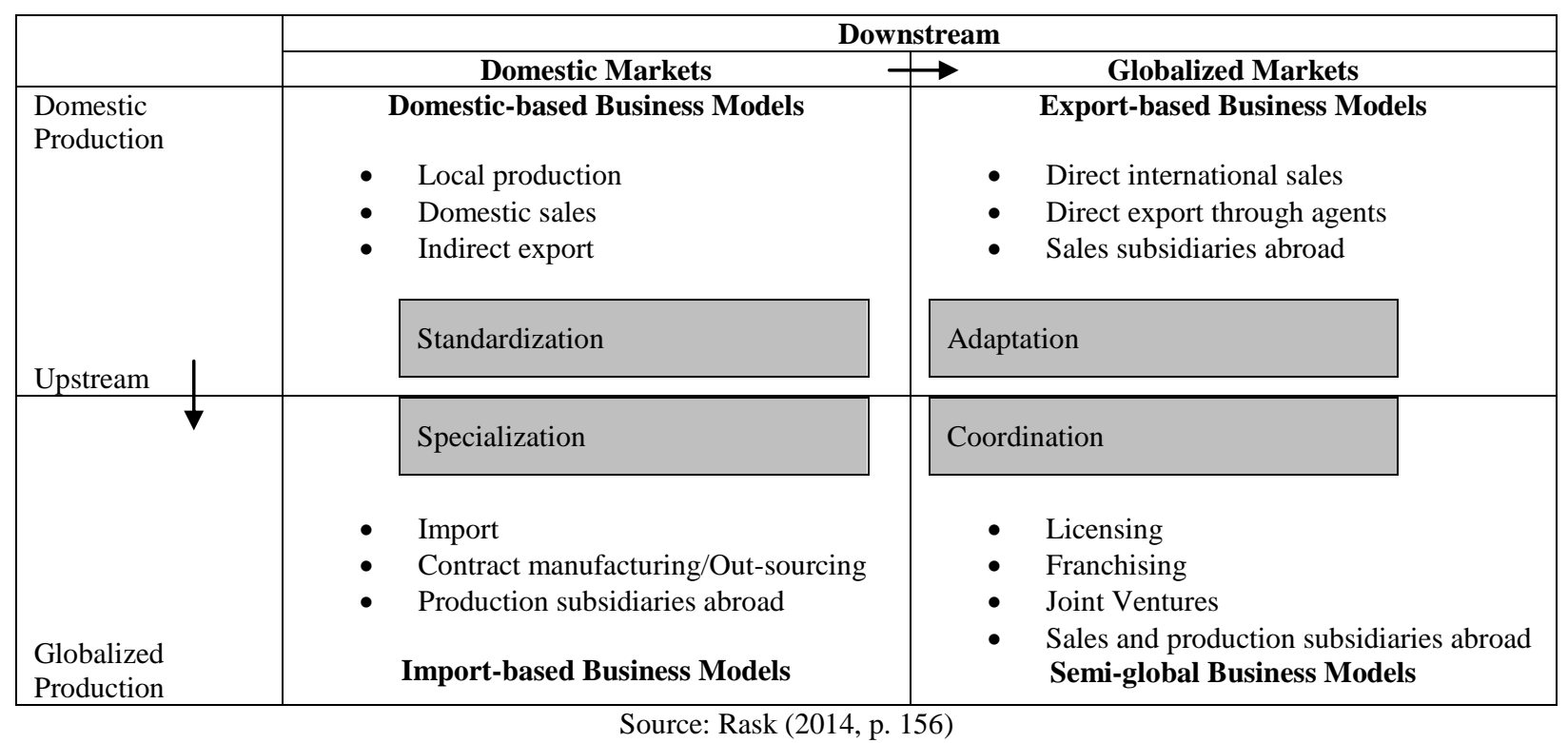

Figure 3: An International Dimension-Driven Business-Model Framework

First of all, in the domestic-based business model, products and services can be sold internationally through other firms, e.g. export houses. When the internationalization speeds up, the firm follows either the path of market or product globalization that involves standardization in areas where no differences are found and leads to the exportbased business model. Regarding customer relationships, channels, segments and the creation of revenue are facilitated by entry modes (e.g. sales subsidiaries abroad) that mediate the international exchange of goods, services, information and capital through the adaptation to small, but important, differences. The other path to the importbased business model also involves standardization in areas with no differences and further specialization with a focus on efficiency. Finally, the semi-global business model reflects a firm's strategic decision that is a combination of standardization, adaptation, and/or specialization that draws on experience from other business models where importing and exporting activities and the ensuing cross-country flow of finances, products and information are coordinated and localized wherever this proves to be most efficient (Hagen et al., 2014; Rask, 2014). Therefore, business model innovation in a global setting has to take domestic and global downstream markets and upstream production into account when designing international business models and encompasses resource allocation for dealing with differences among geographical location as well as entry model elements (Rask, 2014).

Sleuwaegen and Onkelinx (2014) have hinted that "one of the mechanisms behind this successful growth in multiple countries is [...] the flexible adaptation of the business model to foreign market conditions" (p. 118). Moreover, Dunford et al. (2010) highlight that "early and rapid internationalization may be based on expanding into 
new countries via the repeated application of a specific business model [...] and benefit from the experience gained in earlier implementations" (p.657). Therefore, it can be stated that the business model influences the three core characteristics of speed, degree and scope of internationalization and is an important driver of early and rapid internationalization.

\section{DISCUSSION AND FUTURE DIRECTIONS FOR BUSINESS MODEL RESEARCH}

Anchored in the authors' research on BG business models, the authors delineate potential research gaps from the review which can be used as input for further research.

\section{Assessing The International And Innovation Performance Of BGs}

In point of fact, Rask (2014) provides evidence that a business model varies depending on the configuration of the value-creation architecture at the downstream level in the target markets and the upstream level in production. Some interesting insights might also emerge from further investigations of the relationship between business model innovation and the degree of internationalization which could be carried out through empirical surveys, using this model as the theoretical framework. An appropriate measure, from a methodological point of view, are case studies of business-model innovation processes in an international setting to evaluate the conceptual model and exemplify it through existing firms.

\section{Researching The Emerging Concept Of BG Business Models}

In line with these theoretical insights, some interesting research directions need to be further explored in order to clarify to what extent the process of rapid internationalization is influenced by the specific characteristics of business models in different industry sectors and comparing fast and slow firms within this specific industry. Furthermore, when the competitive landscape changes dramatically, firms face the challenge of reassessing their set of activities and deciding which ones to discontinue and which ones to continue; therefore, also from a methodological point of view, longitudinal studies looking at whether or not BGs change their international entry strategies during their life-cycle would be instructive.

\section{CONCLUSION}

The findings suggest that in the past two decades a variety of theories and models from international entrepreneurship research have been applied to describe the distinguishing characteristics of the rapid internationalization process of BGs. Hence, the outcomes of the studies in the sample differ in terms of explanatory power and generalizable assertions and the results of the review indicate several research streams in BG internationalization. At this point, the authors research gives an overview and critically evaluates what has been studied in this field and takes a broad look at present accomplishments in BG research. Therefore, the approaches to accelerated internationalization were clustered in the research areas of the individual level, the firm level and the national level but are not entirely satisfactory to explain the emergence of BGs.

The authors take a different approach and argue that the distinguishing characteristic of BGs may be due to differences in their business models and their ability to adapt them to foreign markets. Thus, one of the aims of this study was to provide an updated and complete assessment of relevant academic articles on BG business models by conducting a systematic literature review. In point of fact, this paper portrays the central structure, foundations and the main avenues of BG business-model research. In a nutshell, the results of this literature review lend credibility to the notion that the business models of BGs have gained increasing interest and are a main accelerator of international performance. Nevertheless, the still fragmented business model concept remains ambiguously defined and the scholarly community is still in the early stages of developing the business model as a pivotal level of analysis in the authors' understanding of BGs and their internationalization process. 


\section{ACKNOWLEDGEMENTS}

This publication was funded by the German Research Foundation (DFG) and the University of Bayreuth in the funding programme Open Access Publishing.

\section{AUTHOR INFORMATION}

Ricarda Bouncken is Chair Professor of Strategy and Organization at the University of Bayreuth, Germany. Her research centers on diversity, innovation, and collaboration. Email: bouncken@uni-bayreuth.de (Corresponding author).

Miriam Muench is a Master's student in Entrepreneurship at the University of Liechtenstein. Prior to this, she completed her BA in Management in Industry with a major in international management and controlling at the Cooperative State University (DHBW) in Baden-Wuerttemberg. Email: miriam.muench@uni.li.

Sascha Kraus is a Professor for Entrepreneurship at the University of Liechtenstein and a Visiting Professor at the University of St. Gallen, Switzerland. He is also an Adjunct Professor at Lappeenranta University of Technology, Finland. Email: sascha.kraus@unisg.ch.

\section{REFERENCES}

Acedo, F. J., \& Jones, M. V. (2007). Speed of internationalization and entrepreneurial cognition: Insights and a comparison between international new ventures, exporters and domestic firms, Journal of World Business, 42(3), 236-252.

Almor, T. (2013). Conceptualizing Paths of Growth for Technology-Based Born-Global Firms Originating in a Small-Population Advanced Economy, International Studies of Management and Organization, 43(2), 5678.

Andersson, S. (2011). International entrepreneurship, born globals and the theory of effectuation, Journal of Small Business and Enterprise Development, 18(3), 627-643.

Autio, E. (2005). Creative tension: the significance of Ben Oviatt's and Patricia McDougall's article 'toward a theory of international new ventures.', Journal of International Business Studies, 36(1), 9-19.

Autio, E., Sapienza, H. J., \& Almeida, J. G. (2000). Effects of age at entry, knowledge intensity, and imitability on international growth, Academy of Management Journal, 43(5), 909-924.

Barney, J. (1991). Firm Resources and Sustained Competitive Advantage, Journal of Management, 17(1), 99-120.

Bell, J. (1995). The internationalization of small computer software firms, European Journal of Marketing, 29(8), 60-75.

Bell, J., McNaughton, R., Young, S., \& Crick, D. (2003). Towards an Integrative Model of Small Firm Internationalisation, Journal of International Entrepreneurship, 1(4), 339-362.

Bingham, C. B., \& Davis, J. P. (2012). Learning Sequences: Their Existence, Effect, and Evolution, Academy of Management Journal, 55(3), 611-641.

Bouncken, R., Schuessler, F, \& Kraus, S. (2015). The Theoretical Embedding Of Born Globals: Challenging Existing Internationalization Theories, International Business \& Economics Research Journal, 14(1), 39-46.

Casadesus-Masanell, R., \& Ricart, J. E. (2010). From Strategy to Business Models and onto Tactics, Long Range Planning, 43(2/3), 195-215.

Cesinger, B., Fink, M., Madsen, T. K., \& Kraus, S. (2012). Rapidly internationalizing ventures: how definitions can bridge the gap across contexts, Management Decision, 50(10), 1816-1842.

Chesbrough, H. (2010). Business Model Innovation: Opportunities and Barriers, Long Range Planning, 43(2-3), 354-363.

Chetty, S., \& Campbell-Hunt, C. (2004). A Strategic Approach to Internationalization: A Traditional Versus a "Born-Global" Approach, Journal of International Marketing, 12(1), 57-81.

DaSilva, C. M., \& Trkman, P. (2013). Business Model: What It Is and What It Is Not, Long Range Planning, (in press).

Dhanaraj, C., \& Beamish, P. W. (2003). A Resource-Based Approach to the Study of Export Performance, Journal of Small Business Management, 41(3), 242-261. 
Dunford, R., Palmer, I., \& Benveniste, J. (2010). Business Model Replication for Early and Rapid Internationalisation: The ING Direct Experience, Long Range Planning, 43(5-6), 655-674.

Eisenhardt, K. M., \& Martin, J. A. (2000). Dynamic capabilities: What are they?, Strategic Management Journal, 21(10/11), 1105.

Evers, N. (2010). Factors influencing the internationalisation of new ventures in the Irish aquaculture industry: An exploratory study, Journal of International Entrepreneurship, 8(4), 392-416.

Fan, T., \& Phan, P. (2007). International new ventures: revisiting the influences behind the 'born-global' firm, Journal of International Business Studies, 38(7), 1113-1131.

Fink, M., Harms, R., \& Kraus, S. (2008). Cooperative internationalization of SMEs: Self-commitment as a success factor for International Entrepreneurship, European Management Journal, 26(6), 429-440.

Forsgren, M. (2002). The concept of learning in the Uppsala internationalization process model: a critical review, International Business Review, 11(3), 257.

Freeman, S., \& Cavusgil, S. T. (2007). Toward a Typology of Commitment States Among Managers of Born-Global Firms: A Study of Accelerated Internationalization, Journal of International Marketing, 15(4), 1-40.

Freeman, S., Edwards, R., \& Schroder, B. (2006). How Smaller Born-Global Firms Use Networks and Alliances to Overcome Constraints to Rapid Internationalization, Journal of International Marketing, 14(3), 33-63.

Gabrielsson, M., \& Manek Kirpalani, V. H. (2004). Born globals: how to reach new business space rapidly, International Business Review, 13(5), 555-571.

Gabrielsson, P., Gabrielsson, M., \& Seppäl, T. (2012). Marketing Strategies for Foreign Expansion of Companies Originating in Small and Open Economies: The Consequences of Strategic Fit and Performance, Journal of International Marketing, 20(2), 25-48.

Grant, R. M. (1996). Prospering in Dynamically-competitive Environments: Organizational Capability as Knowledge Integration, Organization Science, 7(4), 375-387.

Gray, B., \& Farminer, A. (2014). And no birds sing-reviving the romance with international entrepreneurship, Journal of International Entrepreneurship, 12(2), 115-128.

Hagen, B., Denicolai, S., \& Zucchella, A. (2014). International entrepreneurship at the crossroads between innovation and internationalization, Journal of International Entrepreneurship, 12(2), 111-114.

Hennart, J. F. (2014). The Accidental Internationalists: A Theory of Born Globals, Entrepreneurship: Theory \& Practice, 38(1), 117-135.

Jantunen, A., Nummela, N., Puumalainen, K., \& Saarenketo, S. (2008). Strategic orientations of born globals-Do they really matter?, Journal of World Business, 43(2), 158-170.

Johanson, J., \& Vahlne, J-E. (1977). The internationalization process of the firm-a model of knowledge development and increasing foreign market commitments, Journal of International Business Studies, 8(1), 25-34.

Johanson, J. \& Vahlne, J-E. (1990). The Mechanism of Internationalism, International Marketing Review, 7(4), 11.

Jones, M. V., Coviello, N., \& Tang, Y. K. (2011). International Entrepreneurship research (1989-2009): A domain ontology and thematic analysis, Journal of Business Venturing, 26(6), 632-659.

Knight, G. A., \& Cavusgil, S. T. (1996). The born global firm : a challenge to traditional internationalization theory. In S. Tamer Cavusgil \& T. Koed Madsen (Eds.): Advances in International Marketing.

Knight, G. A., \& Cavusgil, S. T. (2004). Innovation, organizational capabilities, and the born-global firm, Journal of International Business Studies, 35(2), 124-141.

Kraus, S. (2011). State-of-the-art current research in international entrepreneurship: A citation analysis, African Journal of Business Management, 5(3), 1020-1038.

Madsen, T. K., \& Servais, P. (1997). The internationalization of Born Globals: An evolutionary process?, International Business Review, 6(6), 561-583.

McGrath, R. G. (2010). Business Models: A Discovery Driven Approach, Long Range Planning, 43(2-3), $247-261$.

Moen, Ø. (2002). The Born Globals: A new generation of small European exporters, International Marketing Review, 19(2), 156-175.

Moen, Ø., \& Servais, P. (2002). Born Global or Gradual Global? Examining the Export Behavior of Small and Medium-Sized Enterprises, Journal of International Marketing, 10(3), 49-72.

Moen, Ø., Sørheim, R., \& Erikson, Т. (2008). Born Global Firms and Informal Investors: Examining Investor Characteristics, Journal of Small Business Management, 46(4), 536-549.

Onetti, A., Zucchella, A., Jones, M., \& McDougall-Covin, P. (2012). Internationalization, innovation and entrepreneurship: business models for new technology-based firms, Journal of Management \& Governance, 16(3), 337-368. 
Osterwalder, A., \& Pigneur, Y. (2005). Clarifying business models: Origins, present, and future of the concept, Communications of the Association for Information Systems, 16(1), 1-25.

Oviatt, B. M., \& McDougall, P. P. (1994). Toward a theory of international new ventures, Journal of International Business Studies, 25(1), 45-64.

Oviatt, B. M., \& McDougall, P. P. (2005). Defining International Entrepreneurship and Modeling the Speed of Internationalization, Entrepreneurship: Theory \& Practice, 29(5), 537-553.

Park, T., \& Rhee, J. (2012). Antecedents of knowledge competency and performance in born globalsThe moderating effects of absorptive capacity, Management Decision, 50(8), 1361-1381.

Phillips McDougall, P., Shane, S., \& Oviatt, B. M. (1994). Explaining the formation of international new ventures: The limits of theories from international business research, Journal of Business Venturing, 9(6), 469-487.

Rask, M. (2014). Internationalization through business model innovation: In search of relevant design dimensions and elements, Journal of International Entrepreneurship, 12(2), 146-161.

Rennie, M. W. (1993). Born global, McKinsey Quarterly, 4), 45-52.

Rialp, A., Rialp, J., \& Knight, G. A. (2005). The phenomenon of early internationalizing firms: what do we know after a decade (1993-2003) of scientific inquiry?, International Business Review, 14(2), 147-166.

Richardson, J. (2008). The business model: an integrative framework for strategy execution, Strategic Change, 17(56), 133-144.

Schuessler, F., Schaper, M. T., \& Kraus, S. (2014). Entrepreneurship in an Alpine micro-nation: the case of Liechtenstein, International Journal of Entrepreneurship and Small Business, 22(1), 106-114.

Sleuwaegen, L., \& Onkelinx, J. (2014). International commitment, post-entry growth and survival of international new ventures, Journal of Business Venturing, 29(1), 106-120.

Steen, J. T., \& Liesch, P. W. (2007). A Note on Penrosean Growth, Resource Bundles and the Uppsala Model of Internationalisation, Management International Review (MIR), 47(2), 193-206.

Teece, D. J. (2007). Explicating dynamic capabilities: the nature and microfoundations of (sustainable) enterprise performance, Strategic Management Journal, 28(13), 1319-1350.

Teece, D. J. (2010). Business Models, Business Strategy and Innovation, Long Range Planning, 43(2-3), 172-194.

Welch, L. S., \& Luostarinen, R. (1988). Internationalization: Evolution of a Concept, Journal of General Management, 14(2), 34-55.

Westhead, P., Wright, M., \& Ucbasaran, D. (2001). The internationalization of new and small firms: A resourcebased view, Journal of Business Venturing, 16(4), 333-358.

Young, S. (1987). Business Strategy and the Internationalization of Business: Recent Approaches, Managerial \& Decision Economics, 8(1), 31-40.

Zott, C., \& Amit, R. (2008). The fit between product market strategy and business model: implications for firm performance, Strategic Management Journal, 29(1), 1-26.

Zott, C., \& Amit, R. (2013). The business model: A theoretically anchored robust construct for strategic analysis, Strategic Organization, 11(4), 403-411. 


\section{NOTES}

